\title{
Factors Affecting Technology Integration in EFL Classrooms: The Case of Kuwaiti Government Primary Schools
}

\author{
Maha Bader Alghasab ${ }^{1}$, Anaam Alfadley ${ }^{1} \&$ Amel M. Aladwani $^{1}$ \\ ${ }^{1}$ College of Basic Education, The Public Authority for Applied Education and Training (PAAET), Ardhiya, \\ Kuwait \\ Correspondence: Maha Bader Alghasab, English Language Department, College of Basic Education, PAAET, \\ Ardhiya, Kuwait. E-mail: mb.alghasab@paaet.edu.kw
}

Received: May 1, 2020 Accepted: May 31, 2020 Online Published: June 19, 2020

doi:10.5539/jel.v9n4p10 URL: https://doi.org/10.5539/jel.v9n4p10

\begin{abstract}
Previous Computer Assisted Language Learning (CALL) research has shown that technology is beneficial for promoting language learning, but some teachers neither use technology as an assisted tool nor integrate it into their language classrooms. It has also been argued that the integration of technology has been unsuccessful in Kuwait. This study aims to explore the factors influencing teachers' use of technology in English as a foreign language (EFL) classroom in Kuwaiti government primary schools. More specifically, it aims to highlight factors promoting and hindering EFL teachers' use of technology. For the purpose of this study, 55 questionnaire responses were collected from different primary school teachers in Kuwait, followed up with 15 semi-structured interviews. The study findings show that Kuwaiti primary school EFL teachers who participated in the current study demonstrated positive attitudes towards using technology and acknowledged the implementation of some cutting-edge technologies in their classrooms. Enhancing students' language learning, innovation and school support were the main factors that encouraged the participating teachers to use technology. Other factors hindered the use of technology; particularly those related to lack of parental support, personal expenses and health problems, teachers' lack of skills and training, poor classroom infrastructure, and time constraints/workload. The findings also reveal that the lack of professional development training workshops provided by the Ministry of Education led the Kuwaiti teachers to rely more on informal training in which they worked and learnt together with their colleagues in small sub-groups to improve their use of technology. The study findings have implications for policymakers and other stakeholders intending to integrate technology in Kuwaiti primary schools.
\end{abstract}

Keywords: technology, language classroom, EFL teachers, factors affecting the use of technology

\section{Introduction}

The rapid evolution of technology had a significant influence on education, particularly in Second/Foreign language (SL/FL) classrooms (Kern \& Warschauer, 2000; Warschauer \& Meskill, 2000). CALL research has reported that the integration of technology in language classrooms has the potential to develop learners' language skills and improve their attitudes towards language learning (Ahmadi, 2018; Macaro, Handley, \& Walter, 2012; Shadiev \& Yang, 2020). However, it is important to note that it is not the technology per se that affects language learning, but particular uses of technology (Kern, 2006). Therefore, teachers' pedagogical practices and attitudes are the main factors influencing the successful integration of technology (Li \& Walsh, 2010; Mumtaz, 2000).

By focusing on teachers, CALL research findings have identified a number of complex factors that affect teachers' use of technology in EFL classrooms (Lam, 2000; Li \& Walsh, 2010; Spiteri \& Rundgren, 2018). The main factors include teachers' Information and Communication Technology (ICT) skills and teaching experience (Egbert, Paulus, \& Nakamichi, 2002), teachers' beliefs and attitudes regarding technology (Lam, 2000), access to appropriate resources, software, and training (Li \& Walsh, 2010; Pelgrum, 2001), parent and community support (Afshari et al., 2009), time constraints (Al-Awidi \& Aldhafeeri, 2017; Mumtaz, 2000), institutional support and school culture (Mumtaz, 2000; Spiteri \& Rundgren, 2018), and teachers' training programmes (Afshari et al., 2009). In addition, technological and organizational infrastructure, the curriculum, expectation and needs should also be considered in order to achieve a successful implementation of technology (Albirini, 2006). These factors are interrelated and the success of technology integration is not determined by the availability or the absence of 
one factor but through a dynamic process involving a set of factors (Afshari et al., 2009).

In the Kuwaiti context, empirical studies have reported that despite teachers' positive attitudes regarding technology integration, there are a number of factors that impede their use of technology in classrooms (Al-Ajmi, 2011; Al-Sharija, Qablan, \& Watters, 2012; Erguvan, 2014). These are related to lack of training (Al-Harbi, 2012) and educational policies that lack clear vision and strategy (Al-Ajmi, 2011). It has also been observed that teachers use technology to support their existing traditional teaching practices, which focus on the teacher-fronted approach (Al Sharjia et al., 2012). Other studies (e.g., Al-Awidi \& Aldhafeeri, 2017) have reported that despite Kuwaiti teachers' moderate technical and pedagogical readiness to use technology, a number of factors have hindered the process of proper implementation. These factors are time constraints, lack of knowledge and skills, inappropriate classroom infrastructure, and lack of technical support. Other cultural, technical, and contextual challenges have also been mentioned by previous studies as hindrances (e.g., Alfelaij, 2016). Therefore, Alfelaij argued that the integration of technology in Kuwaiti government schools has been unsuccessful, and that this failure is the consequence of complex factors.

Despite the efforts made by the Kuwaiti government to implement technology in classrooms, previous studies have identified many factors that affect teacher's decision to implement technology. A review of these studies has revealed that most of them were conducted in the higher education context, and very little research has explored technology integration in Kuwaiti government primary schools (e.g., Al-Harbi, 2012; Alkhezzi \& Abdelmagid, 2011). In addition, previous studies have focused on technology integration in all subjects without focusing particularly on English language classrooms. Therefore, this study aims to bridge this literature gap by focusing on EFL teachers' use of technology and highlighting factors that promote or hinder their use of technology. To this end, the following research questions have been proposed:

- What motivates Kuwaiti government primary school EFL teachers to use technology?

- What prevents Kuwaiti government primary school EFL teachers from using technology?

\section{Literature Review}

\subsection{Diffusion of Innovation Theory}

According to Roger's (2003) diffusion of innovations theory, adopting new innovations is a process, and people tend to explore new technology and seek to experience how effective it is before accepting or rejecting it. Therefore, the theory provides a suitable framework for understanding the process of change and how new innovations spread among teachers. Roger (2003) proposed five main characteristics that impact the rate of adoption: relative advantages, compatibility, trialability, observability, and complexity.

- Relative advantages: to accept an innovation, an individual must perceive adoption of the innovation as advantageous (e.g., economic advantage and social prestige).

- Compatibility: The degree to which an innovation is perceived as being consistent with the individual's values, needs, and past experience. The more compatible the innovation is with the needs of individuals, the faster it will be adopted.

- Trialability: The degree to which an innovation can be tested on a limited basis to check its suitability. Trials increase the likelihood of the adoption of the innovation by decreasing ambiguity related to its use.

- Observability: How visible the results of the innovation are to other individuals. People tend to adopt a new innovation when it has clear benefits and positive results.

- Complexity: The degree of difficulty of understanding and using the innovation. A simple and easy innovation is more likely to be adopted and accepted by individuals than a complex one.

\subsection{Factors-Affecting Teachers' Use of Technology}

Previous studies on the use of technology in classrooms have revealed that the process of implementation is complex and involved different influencing factors (Spiteri \& Rundgren, 2018). These factors are classified into different categories; for example, Afshari et al. (2009) discussed non-manipulative factors (e.g., teacher's age, teaching experience, computer experience and external support from school) and manipulative factors (e.g., teachers' attitudes towards technology, teachers' ICT skills and the availability of technology). ChanLin et al. (2006) classified these factors as environmental (e.g., school computer facilities and budget), personal (e.g., teachers' belief, interest, and experience regarding the use of technology), social (e.g., support from community, technology trends and social change) and curricular (e.g., skills, literacy, teaching loads and ease/difficulty of using technology). Likewise, Spiteri and Rundgren (2018) discussed four main factors: school culture (e.g., 
infrastructure, peer coaching and support), teachers' knowledge (e.g., pedagogy, teachers' training and curriculum), teachers' attitudes (e.g., confidence, innovation, perceptions and motivation) and teachers' skills (e.g., computer proficiency, new roles and evolving technologies). The following sections synthesize existing research findings into factors that encourage/discourage teachers' use of technology in classroom.

\subsubsection{Factors That Encourage Technology Use}

Existing literature has reported various factors that positively affect technology integration in classrooms generally and in EFL classrooms specifically, including the popularity of ICT as a support for learning, teachers' desire to change current teaching methods, and the benefits for teachers and students (Al-Awidi \& Aldhafeeri, 2017; Li \& Walsh, 2010). Teachers' creativity has also been identified as a factor. That is, creative teachers who are life-long learners and decision makers are more inclined to use technology than other teachers (Afshari et al., 2009). In addition, parent and community support has been shown to play a significant role in assisting teachers with technology integration (Afshari et al., 2009). When parents contribute to a school's ideas (e.g., technology use), changes occur quickly. Institutional support, which refers to support for individual teachers in schools (e.g., from their colleagues and the school principal) through motivation, rewards, or incentives has also been shown to encourage teachers to use technology (Al-Kafyulilo, Fisser, \& Voogt, 2015; Eickelmann, 2011; Harvey \& Hurworth, 2006; Li \& Walsh, 2010).

According to Mumtaz (2000), factors that may encourage teachers to adopt technology are related to either teaching practices (e.g., making the lesson more interesting, easier, enjoyable, diverse and motivating for the teachers and their students) or teachers' personal preferences (e.g., improving the presentation of materials, giving more power to teachers in school, and giving teachers more prestige). This echoes Lam's (2000) findings, which suggested that factors that encourage teachers to use technology are the ability of the technology to provide a different mode of presentation, to motivate students, and to offer authentic materials. Other studies have found that teachers who often use technology have experienced teaching with technology in their pre-service course and received support from their colleagues to get new CALL activity ideas (Egbert et al., 2002).

Research has also highlighted the importance of the availability of resources including software and hardware. As stated by Afshari et al. "efficient and effective use of technology depends on the availability of hardware and software and the equity of access to resources by teachers, students and administrative staff" (2009, p. 85). Likewise, Li and Walsh (2010) found that the availability of hardware motivated teachers to try using technology. Additionally, culture and teachers' positive perceptions regarding technology have also been shown to have an impact; that is, teachers who have positive perceptions of the cultural relevance of technology will adopt technology in their teaching (Albirini, 2006; Spiteri \& Rundgren, 2018). Moreover, Li and Walsh (2010) argued that teachers are motivated to use technology in order to meet the expectations of other people (e.g., students' parents).

Finally, Egbert et al. (2002) and Spiteri and Rundgren (2018) argued that informal learning (i.e., teachers learning from each other through the exchanging of ideas and experience in using technology) motivates teachers to use technology. Similarly, Zhao and Frank (2003) suggested that informal learning among teachers in schools has a positive influence on the implementation of technology, since learning occurs in social settings where colleagues influence one another's beliefs and attitudes towards using technology.

\subsubsection{Factors That Discourage Technology Use}

Lack of resources, including software, digital devices, computers or IPads, has been identified as a common barrier to technology integration (Albirini, 2006; Pelgrum, 2001). Al-Awidi and Aldhafeeri (2017) argued that although some technologies were available in Kuwaiti government schools, the classroom infrastructure was not suitable for technology integration and the availability of resources was inadequate. Furthermore, Alfelaij (2016) discussed many technical factors that impede technology integration in Kuwaiti schools, for example: inaccessibility, low usability, inconvenience, slow internet speed, lack of infrastructure, computer unavailability, lack of pedagogical vision, and lack of understanding of what it takes to transfer printed materials to an online format. These findings substantiated globally felt obstacle that access to technology is one of the most significant factors affecting technology adoption (Pelgrum, 2001). For example, in China, despite the large number of CALL products available to EFL teachers, responses to a questionnaire conducted by $\mathrm{Li}$ and Walsh (2010) indicated that $77 \%$ of the participants encountered a lack of relevant software packages including courseware.

Teachers' computer competence, training they received and levels of confidence when using technology are also factors that impede technology use. Previous research has suggested a correlation between teachers' computer competence and their use of technology (Al-Awidi \& Aldhafeeri, 2017; Albirini, 2006; Pelgrum, 2001; Spiteri \& 
Rundgren, 2018). In a study conducted by Al-Awidi and Aldhafeeri (2017), most of the Kuwaiti teachers declared that they had a high level of technical skill in using technology but they lacked the knowledge and skills to integrate technology in their classrooms. Furthermore, the majority of the teachers stated that they had never attended any technology training workshops. Accordingly, Al-Awidi and Aldhafeeri (2017) argued that the training given by the Ministry of Education in Kuwait is not effective since it focuses more on technical skills and technology itself rather than on teaching with technology (i.e., pedagogy). It is not just advanced skills that are essential to integrating technology successfully, but also teachers' confidence in using these skills to achieve better learning outcomes (Alfelaij, 2016; Cox et al., 2003; Lam, 2000). Research has also indicated that a large number of teachers still fear using technologies in the classroom (Cox et al., 2003), while others feel anxious, uncomfortable, and unconfident (Lam, 2000; Li \& Walsh, 2010). Shyness, lack of self-confidence, and poor English proficiency (most LMS educational tools are in English) are other factors that affect teachers' confidence in using technology and consequently affect teachers' technology use negatively (Alfelaij, 2016).

Lack of on-site technical support for teachers also plays a key role in teachers' technology use (Al-Awidi \& Aldhafeeri, 2017; Jones, 2004; Mumtaz, 2000; Pelgrum, 2001). According to Jones (2004), teachers may face two types of technical difficulty: fear of things going wrong and lack of technical support. In a study of Chinese teachers, Li and Walsh (2010) found that the lack of technical support prevented $42 \%$ of the participants from using technology. Similarly, Al-Awidi and Aldhafeeri (2017) found that 57\% of their study participants complained about technical problems. Although some teachers in their study mentioned the availability of technical support in their schools, they complained about the time taken to resolve problems. Moreover, Alfelaij (2016) found that government schools in Kuwait suffered due to a shortage of computers in class, poorly equipped lecture halls, a shortage of technicians, a lack of maintenance, out-dated software, and insufficient numbers of computers.

Lack of time has been frequently reported as a factor that negatively affects technology integration (Al-Awidi \& Aldhafeeri, 2017; Alfelaij, 2016; Mumtaz, 2000; Li \& Walsh, 2010). Previous studies have identified time constraint as a factor that makes teachers reluctant to use technology. For example, Al-Awidi and Aldhafeeri found that $85 \%$ of teachers complained about a heavy teaching load and that they did not have time to prepare computer-based activities. In addition, the curriculum design was not sufficiently flexible to allow technology implementation. Likewise, in Li and Walsh's (2010) study, 71\% of teachers reported similar concerns, that using technology was time-consuming and resulted in increased workload.

Other factors such as lack of teachers' technology training and lack of institutional support have also been documented as barriers to technology use (Afshari et al., 2009; Li \& Walsh, 2010; Warschauer, 2002). Afshari et al., (2009) suggested that inadequate preparation for using technology is one of the reasons for teachers' technology avoidance. They stated that "teachers are likely to integrate ICT in their courses, when professional training in the use of ICT provides them time to practice with the technology and to learn, share and collaborate with colleagues" (Afshari et al., 2009, p. 89). 52\% of Chinese teachers in Li and Walsh's study asserted that they needed pedagogical training to use technology. In addition to training, institutional philosophies and policies have been shown to have a profound impact on technology integration. Class size, exam-based curricula, and students' dedication to teacher-centred approaches, insufficient administrative support and fear of change all hinder technology use (Alfelaij, 2016; Spiteri \& Rundgren, 2018).

\section{Method}

The purpose of this study is to explore EFL teachers' use of technology in Kuwaiti government primary schools and to consider the main factors that influence their decisions to use technology in the classroom. Exploratory descriptive case studies are most advantageous when little has been written about the topic or population being studied (Creswell, 2007; Yin, 2009). Furthermore, the exploratory case study design helps to obtain understanding of contextual issues, which are considered essential in CALL studies. To understand the effectiveness of the use of a particular technology, there is a need to understand the sociocultural context in which it has been adopted (Chambers \& Bax, 2006; Kern, 2006). Sociocultural context here not only refers to physical environment, it also includes participants' ideologies, values, and histories (Holloway \& Wheeler, 2002). Adopting another methodological approach could have led to what Gutierrez (2006) termed a techno-centric perspective (i.e., focusing on technology only) whilst ignoring the effect of agency (i.e., participants with their own goals, attitudes, and histories). The following section describes the research participants, research procedure, the data collection and analysis.

\subsection{Participant}

A total of 55 female EFL teachers participated in the study. They were working in government primary schools 
in Kuwait. Although schools are segregated according to student gender, the majority of primary school teachers in Kuwait are female. Therefore, all the participants in this study were female. Table 1 presents the demographic characteristics of the participants based on the questionnaire data (Appendix A). As shown, the majority of participants were aged twenty to twenty-five and had a Bachelor's degree. Most of the participants had graduated from the College of Basic Education (78.2\%), and 21.8\% had graduated from Kuwait University. The teachers had varied teaching experience, with the majority $(67.3 \%)$ reporting one to five years experience. Finally, $43.6 \%$ of the participants declared that they had an International Computer Driving licence (ICDL) certificate.

Table 1. Demographic characteristics of EFL teachers

\begin{tabular}{llll}
\hline Demographic characteristics & Frequency & Percentage \\
\hline Gender & Female & 55 & $100.0 \%$ \\
Age & 20 to 25 & 27 & $49.1 \%$ \\
& 26 to 35 & 17 & $30.9 \%$ \\
& 36 to 45 & 9 & $16.4 \%$ \\
Education & 46 to 55 & 2 & $3.6 \%$ \\
\multirow{5}{*}{ Graduated from } & Bachelor & 50 & $90.9 \%$ \\
\multirow{3}{*}{ Teaching experience } & Master & 5 & $9.1 \%$ \\
& Kuwait University & 12 & $21.8 \%$ \\
& College of Basic Education & 43 & $78.2 \%$ \\
& from 1-5 years & 37 & $67.3 \%$ \\
Technology training & from 6-10 years & 6 & $10.9 \%$ \\
& from 22-20 years & 9 & $16.4 \%$ \\
ICDL & from 20-30 years & 3 & $5.5 \%$ \\
& No & 34 & $61.8 \%$ \\
& Yes & 21 & $38.2 \%$ \\
& No & 31 & $56.4 \%$ \\
& Yes & 24 & $43.6 \%$ \\
\hline
\end{tabular}

\subsection{Research Procedure}

The study was conducted in November 2019. Questionnaires were distributed online using Google forms and shared with teachers via a teachers' WhatsApp group. A total of 55 responses were received from participants, who were asked in the survey if they were willing to participate in an interview on their use of technology in the classroom. Only 15 teachers volunteered to take part in the interview. In December 2019, permission was obtained from the Ministry of Education to visit the two schools where the 15 teachers were working. After being informed about the study, the chosen participants were provided with a consent form that was verbally translated to provide explanation of what the interviews would entail. Participants were told that they had the right to withdraw from or stop the interview at any time.

\subsection{Data Collection and Analysis}

Two main data collection instruments were used: a questionnaire and semi-structured interviews. A combination of different tools helps to validate the results of the study and hence generate more reliable conclusions.

The development of the questionnaire was guided by previous studies in the literature ( $\mathrm{Li} \& \mathrm{Walsh}, 2010$ ). Some changes were made to the original questionnaire to match the current study's objectives. For example, Li and Walsh's (2010) questionnaire was designed to understand different factors such as the ICT environment in China, teacher's skills and training and their use of ICT, including factors that motivate/prevent teachers' use of ICT. In designing the questionnaire for the current study, the researchers focused primarily on factors that promote/prevent teachers' use of technology without including other sections mentioned in the original questionnaire. To enhance face validity, four experts evaluated the questionnaire and some statements were changed accordingly to ensure that the content was culturally and technically appropriate for the Kuwaiti context. All the correlation coefficients between items and themes were significant at the 0.01 levels, which indicated suitable internal consistency. The reliability of the questionnaire was measured using SPSS and an acceptable Cronbach's Alpha coefficient of 0.896 was calculated. The questionnaire was distributed online because of the ease of access this provided and to ensure the anonymity of research participants (Sue \& Ritter, 2007). To analyse the questionnaire, SPSS was used to present frequencies and percentages for teachers' questionnaire responses.

To gain an in-depth understanding of the teachers' use of technology and factors that affected their level of use, 
semi-structured face-to-face interviews (see Appendix B) were conducted with 15 female teachers from two primary schools who were selected using a convenience sampling. That is, all teachers were given the option to take part in follow-up semi-structured interviews and only those who volunteered were considered for participation. The main purpose of such interviews is to examine and understand the feelings, opinions, beliefs, and perceptions of research participants (Miles \& Huberman, 1994). Interview themes focused on elaborating further on the questionnaire items. The teachers were asked to talk about their attitudes towards using technology inside the classroom, their actual practices in relation to technology integration, and the reasons why they $\mathrm{did} / \mathrm{did}$ not use technology in their classrooms. The majority of the interviews were conducted in English (twelve interviews), and some were conducted in Arabic (three interviews) according to teachers' preferences. The researcher translated the interviews verbatim for the analysis. Each interview lasted from ten to fifteen minutes and was recorded with the teacher's permission using an IPhone 11.

Thematic analysis was employed for analysing the interview data. Two main categories were considered when analysing the data: factors that seemed to promote/hinder the use of technology in the classroom. Nvivo, the qualitative data analysis software was used to facilitate the data coding. When presenting interview's extracts, pseudonyms were used to protect participants' identities.

\section{Results}

\subsection{What Motivates EFL Teachers to Use Technology?}

Several points emerged from the data regarding factors that motivate teachers to use technology. These points related mainly to students' educational gain, teachers' desire to change the way they normally teach and school support:

- Benefits for both teachers and students (e.g., learning better, teaching in an easy and efficient way, increasing learners' motivation, using authentic materials, reducing workload, saving teachers' money, and helping teachers get promoted/receive incentives).

- Innovation and change (making teaching enjoyable, improving teachers' ICT skills, perceiving technology as a trend, changing teaching practices, and breaking the classroom routine).

- School support (encouragement from the school principal and colleague support).

\subsubsection{Benefits for both Teachers and Students}

Most of the teachers declared that they use technology due to its effectiveness to enhance students' learning and facilitate the teaching process. One of the participants, who had been teaching for thirteen years, stated:

"Technology is part of teaching English. Whenever you are using an app you will have to use English, since most of the technologies are in English nowadays, so my main concern is I want my students to acquire the language to improve their English language... It also saves my efforts in class and delivers the information quicker." (Teacher Sara).

Another teacher reiterated this point by claiming that technology provides teachers with unlimited teaching materials that not only benefit learners but also teachers. According to this participant, using authentic materials and videos on YouTube deliver information to learners not only in an enjoyable way but also in an effective way:

"Well I am using technology, yes, definitely, it is part of my lesson. Not part actually; I am using technology most of the time... It helps me, so rather than wasting my time explaining something, I can easily illustrate it using pictures and videos on YouTube. Students can listen to accurate accents from native speakers... My students love it, they like this way of teaching." (Teacher Noha)

The teachers' questionnaire responses corresponded with what the teachers said in the interviews. For example, the majority $(89.1 \%)$ of the teachers' responses regarding the effectiveness of using technology for learning English were positive. Furthermore, most of the teachers (90.9\%) agreed that technology helped their students to practise grammar with immediate feedback, and a similar percentage agreed that it provided students with authentic materials, which they perceived as beneficial for language learning. Teachers also believed that technology helped them to practise their teaching in a proficient way; $92.7 \%$ of teachers declared that using technology helped them to present their work better, and $72.7 \%$ claimed that it reduced their workload in the classroom. The participants also acknowledged that they used technology because it not only reduced their workload but also saved them money. For instance, teacher Manal explained this:

"I am very into using technology because it saves my money... with technology, I do not have to buy educational materials such as wall charts, flashcards, or educational games, everything is available on the web so I just need to present it for students. It absolutely saves my efforts and money." (Teacher Manal) 
The teachers also believed that using technology in the language classroom helped to promote classroom interaction. For example, $76.4 \%$ of the teachers believed that teacher-student interaction in the classroom was improved by the use of technology. Another reason identified for using technology was to promote learners' motivation. The participants perceived technology as a motivational tool, with $89.9 \%$ agreeing that children who did not like learning were highly motivated when technology was used. Teachers Sara and Shahad elaborated on this point:

"I am using technology every day because I want to grab students' attention. I want to motivate them. I feel they are waiting for me to show them different pictures, videos, and they like this way of teaching." (Teacher Sara)

"Motivation is what pushed me to use technology. Well, it is not easy to use technology daily because you will be carrying all the stuff to the classroom, but I have to because I feel that most of my students, even weak students, are highly motivated. They raise their hands, want to participate and play games when technology is there." (Teacher Shahad).

In addition to educational benefits for both learners and teachers, receiving incentives was another key reason for using technology identified by the respondents. Indeed, $90.9 \%$ of the teachers declared that was easier to get promoted when they used technology. They also confirmed that they used technology to comply with the Ministry of Education assessment criteria. Additionally, $60.2 \%$ of the questionnaire respondents indicated that they were forced to use technology in the classroom. As teacher Mona explained:

"At the beginning I was not using technology; however, my senior teacher told me, 'You must use technology if you want a good grade.' She emphasizes this each time she visits my class. I mean simply, if you want incentives, you should have good grades, and if you want good grades you must use technology." (Teacher Mona)

\subsubsection{Innovation and Change}

Findings also revealed that teachers' motivation and desire to change encouraged them to integrate technology. They perceived technology as a way of improving their teaching practices, keeping up-to-date with modern trends, and meeting their students' expectations. The majority of the teachers $(90.9 \%)$ used technology because it was trendy. The teachers also wanted to bridge the gap between themselves and their students, who they defined as digital natives. Teacher Shayma (forty-five years old), who had been teaching for twenty years, mentioned that she tried to develop her technology skills in order to meet her students' expectations:

"I am using technology a lot because I do not want to be different from my students. They know everything in technology, how to use IPads, how to download an App, and how to play electronic games. I do not want them to feel that I am old and cannot use technology. I really want to meet their expectations to see me as a modern teacher not an old fashioned one." (Teacher Shayma)

In addition, the teachers revealed that they were bored by their usual classroom routine, and agreed that one way to change this was by using technology. In the questionnaire, most of the teachers $(96.4 \%)$ indicated that they used technology because they liked innovation, and $90.9 \%$ declared that technology helped them to change their teaching practices. All the teachers $(100 \%)$ believed that technology helps making teaching enjoyable. The teachers' interviews substantiated the questionnaire responses. For example, teachers Amna and Khlood mentioned that technology helped them to break their teaching routine and to make the teaching process enjoyable:

"Having the same routine every day is boring. Teaching itself is hectic... By the end of the term you feel bored of repeating and doing the same routine... I found technology helpful to breaking this routine, to changing the way I am teaching, and to changing the classroom atmosphere." (Teacher Amna)

"Technology is useful. I really like technology, it changed my students' mood; it is fun and enjoyable, especially when you use online games. Very effective with primary school students, and it breaks the classroom routine" (Teacher Khlood).

\subsubsection{School Support}

The interviews also revealed schools as an essential factor in encouraging teachers to embrace technology. School support in this sense is represented by a school's perspective regarding technology (i.e., whether a school administration encourages/discourages teachers to use technology). Hajer was a senior teacher who had been teaching in primary schools for fifteen years. She explicitly mentioned the role of her school in encouraging teachers in her department and other departments to use technology: 
"When I was in my previous school, I was not using technology; however, I moved here in 2012 and since that time technology has become part of my daily lessons, because our school's principal encourages us to use technology." (Hajer, senior teacher).

Teacher Heba and Noha, from a different school where technology was predominantly used, reiterated what the teacher above described:

"In our school, everything should be done electronically; we have a school Instagram and we post our school's activities for children's parents to see and communicate with us. Being in a school like this has encouraged me to use technology in my class." (Teacher Heba)

"My school principal is the one who pushed me to be a technology user; she always writes positive notes about my lessons because I use technology. This encouraged me to keep using technology in my daily classroom." (Teacher Noha)

As the above interviews extracts showed, school principals had an impact on the teachers' use of technology. In addition, the questionnaire data indicated that teachers themselves influenced each other. For example, most $(80 \%)$ of the teachers reported using technology because their colleagues were keen to use technology in teaching, and $70 \%$ of them used technology because they did not want to be different from other teachers. Teacher Shayma described this by saying "I am using technology because everyone in my department is using technology. I do not want to be old fashioned teacher and I do not want to be odd". Similarly, teacher Hajer explained "In my department, when one teacher uses technology, other teachers feel jealous which is good because this pushes them to use technology too." Meanwhile, teacher Amal described it as a competition "we are working cooperatively; however, when it comes to technology, we are competing to exhibit the best of our work, every teacher tries to use different technologies and Apps for creativity purposes". This was also mentioned by teacher Mona, who stated, "I would like to be creative among my colleagues, our school's principal and senior teachers are supportive of technology."

\subsection{What Prevents Teachers from Using Technology?}

Several issues hindering the use of technology were identified in the questionnaire and interview data. These issues related to broader contextual issues such as parental support and classroom context and specific issues such as teachers' skills, time, training, teachers' duties, and expenses:

- Lack of parental support (rejection from parents and their negative attitudes towards using technology).

- Lack of resources and inadequate classroom infrastructure

- Personal expenses and health problems

- Lack of teachers' skills and training (lack of formal training, teachers' limited ICT skills, teachers' uncertainty regarding technology).

- Time constraints (school's duties and heavy workload)

\subsubsection{Lack of Parental Support}

One way to successfully integrate technology in classroom activities is through links with the wider community. Here, the wider community refers to students' parents and home, since home life can influence a school's success in technology integration. The majority of the teachers $(90 \%)$ in the current study reported needing more understanding and support from students' parents. Some teachers complained about parents' rejection of technology integration, which hindered the use of technology not only outside the classroom but also inside the classroom. For example, teacher Heba, who had been teaching for ten years, complained about some parents:

"Although parents are excited about using technology, when it comes to assigning homework or online activities, they become quite anxious. One day I asked students to participate in online activities on Google Classroom, a few of them participated while the majority told me that their parents did not allow them to connect to the internet and do their homework." (Teacher Heba)

Other teachers identified parents themselves as critical factors, arguing that if parents are supportive, teachers can implement technology outside the classroom. Teacher Noha reported that some parents were unaware of the effectiveness of using technology not only inside the classroom but also outside the classroom, and explained that they did not have a clear and coherent sense of why their children should use technology:

"Parents are not aware of the benefits of technology for their children. One parent came and complained about the extra online activities that I am giving my students, she told the school principal that she does not have time to watch her child while doing these online activities." (Teacher Noha) 
Similarly, teacher Abeer discussed this issue by criticizing the negative perspective of parents towards online learning. She further criticized the Ministry and school's reaction towards parents' complaints by saying:

"The problem lies in our educational system. When parents refuse to let their children use technology inside or outside the classroom, there should be a reaction from the school's principal or the Ministry, for example, to raise parents' awareness about the effectiveness of technology. Unfortunately, this is not happening in our schools." (Teacher Abeer)

The teachers also described encountering challenges regarding the implementation of technology that requires an Internet connection. For example, teacher Manal mentioned that she could not use Kahoot effectively because students were not allowed to bring their IPads into the classroom:

"Kahoot is one of my favourite technologies and it is very interesting for children, but unfortunately I could not use it because no one in the class brought iPads. When I asked my students, they told me that their parents refused." (Teacher Manal)

Teacher Shayma also mentioned that she faced problems with students' parents who did not allow students to bring their IPads to school, which prevented the effective use of technology:

"We need to use IPads for some interactive online activities, but whenever I asked students to bring their own IPad, their parents came to school and complained. One day I talked with a student's mom and she told me that, 'This is not teaching, students are supposed to go and learn in school not play with their IPads.' I personally think parents need to be aware of the effectiveness of technology and IPads in teaching and learning process" (Teacher Shayma)

\subsubsection{Lack of Resources and Inadequate Classroom Infrastructure}

Lack of technological tools in classrooms was reported by most of the teachers as a significant factor that prevented them from using technology. The questionnaire data showed that $83 \%$ of the teachers reported not having any type of technology to use in teaching, and $60 \%$ reported that there were not enough electronic resources. Furthermore, $76 \%$ reported lacking access to their school's computer lab and $89 \%$ stated that they did not have any relevant software packages to use in teaching. Also, $89 \%$ of teachers declared that they needed technical support, which was not available in their school. The interviews elaborated on these findings, as all 15 interviewed teachers reported that their schools were not equipped with different kinds of technological tools or electronic resources. For example, teacher Mona explained, "we do not have technologies, if we want to use technology, we must bring our own devices, including our own PCs, IPads, data show projector which is very exhausting." Other teachers complained about the classroom infrastructure, for example teacher Abeer said that "the classroom has big windows and when I use the projector, the pictures are not very clear, although I always bring my own devices, the Internet connection is very slow and poor". Similarly, other teachers complained about the lack of sockets in classrooms; for example, teacher Amna said: "I need to plug in my computer and data show projector, and classrooms have only one or two sockets and some of them are not working". Four teachers mentioned being unable to connect their smartphone with the data show projector, and teacher Shahad elaborated, "using my smartphone is not professional, sometimes calls interrupt my lessons and sometimes I receive messages which can be displayed for students."

In addition to these issues, the lack of on-site support was identified as a key reason for avoiding technology use. All the respondents stated that they did not receive proper technical support in the classroom whenever technical problems arose. Consider teachers Manal's and Noha's comments on this issue:

"What prevents me from using technology is the technical problems that occur. While I am busy trying to sort out these technical issues, students misbehave and I cannot control the classroom. It's time consuming." (Teacher Manal)

"We do not have any technician in school. Sometimes my own computer fails to work and some programs cannot be launched. I have always been frightened of sudden technical problems, especially when my senior or my supervisor attends my lessons. That's why I sometimes avoid using technology." (Teacher Noha)

\subsubsection{Personal Expenses and Health Problems}

The interviews revealed that all the teachers used their personal technology devices. The respondents explained that the lack of resources led them to use their personal devices such as PCs, IPads, and data show projectors, which they stated was inconvenient and costly. For example, teacher Mona mentioned that carrying these devices was exhausting and caused her backache: 
"I am very interested in using technology, but the fact that I need to bring my own devices every day is exhausting... They are very heavy to carry. I had a backache, that's why I stopped using technology every day. I only use it when I have a demo lesson." (Teacher Mona)

Teachers Khlood, Shayma, and Batool mentioned that in addition to the physical inconvenience of using their own devices, their devices were also vulnerable to malfunction and loss, but they would not be able to receive compensation for any repairs or replacements:

"I use my own devices. I carry them and set up the data show projector in class, which requires effort. Sometimes I ask students to help me. One of the students accidentally hit the table and the data show projector stopped working. I could not repair it since the projector lens was broken; the only option was to buy a new device, which cost me a lot. No one paid for it for me." (Teacher Khlood)

"I am very positive about using technology because my students are very into technology, however, when things go wrong no one cares, I lost my IPad in school and this was my personal IPad my pictures and files are all there but no one reimburse me." (Teacher Shayma)

"I was teaching boys and while I was teaching one of the naughty student cut off my data show projector wire this was annoying I could not do anything and the senior teacher blamed me for my inability to control the classroom" (Teacher Batool)

\subsubsection{Lack of Teachers' ICT Skills and Training}

Teachers' questionnaire responses revealed that a very high proportion (81\%) encountered difficulty when using technology in the classroom, and $78.9 \%$ did not know how to integrate technology into their teaching practice. When asked about their confidence in using technology, $50 \%$ of the teachers reported lacking the confidence to use technology in front of their students. The interviews further highlighted these points, especially those related to level of confidence and capability in using technology. Teachers Mona and Shayma considered themselves incompetent in using technology, which they explained hindered the process of integrating technology in the classroom. For example:

"I really feel embarrassed when technology does not work properly. I just pretend in front of my students that I know everything and I can handle it, but in reality, I do not know what to do, that's why I would avoid using technology." (Teacher Mona)

"Using technology, especially in class in front of my students, is not that easy. Sometimes websites and games do not work and other technical problems happen which cause disappointment not only for my students but also for me. I do not know how to handle these problems." (Teacher Shayma)

Similarly, teacher Batool described an embarrassing situation that occurred when her senior teacher visited her:

"I was explaining something on the board and I turned the data show projector on, but the links on the PowerPoint were not active, and later I noticed that the Internet was disconnected because someone called me on my phone. I could not handle the situation and students started looking at each other and smiling." (Teacher Batool)

The questionnaire data revealed that the majority (90\%) of the teachers were keen to receive training on how to use technology, and $88 \%$ reported needing pedagogical training for implementing technology in their classroom. The interviews uncovered further points regarding insufficient training and the disparity between the Ministry of Education recommendations and the available training workshops, as teacher Khlood commented:

"I really want to improve my skills in using technology, but the Ministry of Education does not offer any formal training on this. It is funny because my supervisor from the Ministry asked us to use technology without offering any training on how we can integrate technology in our classes." (Teacher Khlood)

Other teachers reiterated this point by noting that formal training workshops were rarely offered to them. As a result, they reported frequently engaging in informal training workshops, organized by the teachers themselves for their colleagues, in which they shared the different technologies, software, or Apps they were using and taught their colleagues how to use them. Most of the teachers' descriptions suggested that these informal training sessions focused on technical rather than pedagogical training:

"Since the Ministry of Education does not offer technology training programs or workshops, we as teachers organize in-school workshops and invite other teachers from other departments. We share our experience and discuss the best technological tools for our classrooms." (Teacher Hanan)

"I really want to have formal training on how we can use technology, unfortunately no one helps us on this. 
As colleagues, we are assisting each other. One of my colleagues taught me step-by-step how to use Keynote, FlipQuiz and Quizlet." (Teacher Shayma).

"For me, I learnt everything from my colleagues in the department. They helped me with how to organize my lesson plan, and sometimes I borrow their data show projectors. We are helping each other. We discuss the latest apps and share them on our WhatsApp group. Whenever I face technical problems, I usually seek help from one of my colleagues who is highly competent in using technology.” (Teacher Batool)

\subsubsection{Time Constraints}

In addition to the lack of training and insufficient skills, teachers also mentioned lack of time as a factor that hindered their use of technology. A significant number of teachers $(76.9 \%)$ reported that they did not have time to prepare their lessons using technology. In addition, the teachers already felt they had too much to do. Teachers Amna and Hanan commented on this, highlighting the fact that they had other school duties that prevented them from using technology. Teacher Amna said, "I agree that technology can save your class time, but preparation takes a long time, especially when you are designing games and online quizzes. This takes hours, which wastes my time." While teacher Hanan said "I like using technology; however, I don't have time for it. Using technology requires time to train yourself, and thinking carefully about how you will use it takes time." Teacher Shayma explained that school's duties prevented her from using technology:

"For me, I love to use technology but sometimes other duties prevent me. I have to prepare and attend department meetings, correct students' notebooks and exams, prepare worksheets, and engage in other school activities. I know that technology is helpful, but sometimes I don't have time, and if I was given extra time, I would spend it finishing my other duties, such as preparing exams and correcting student's work" (Teacher Shayma)

\section{Discussion}

This study explored EFL primary school teachers' use of technology in Kuwait. The main finding of this study showed that teachers hold positive attitudes towards technology integration, which corroborates other research findings (Al-Awidi \& Aldhafeeri, 2017; Al-Ajmi, 2010; Alkhezzi \& Abdelmagid, 2011). Findings revealed that EFL government primary school teachers in Kuwait are encouraged to use technology due to their beliefs in the relative advantages of technology (Roger, 2003). In this study, teachers declared that they implement technology due to its economic advantages (saving money, helping teachers to get promoted and incentives) and social advantages (social prestige, being innovative and creative teachers). Besides, teachers used technology due to their beliefs that technology has a positive impact on their performance as teachers (e.g., teaching in effective ways, reducing workload, breaking classroom routine, saving teachers' class time) and on students' learning (e.g., learning better, increasing students' motivations and providing learners' with authentic materials). This confirms Roger's (2003) argument, which is related to the obervability; agreeing with Roger we noticed that teachers are motivated to use technology because it has observed benefits for themselves and their students. These findings supported previous research findings, which reported that teachers use technology due to the benefits technology provides for the teaching and learning process (Ahmadi, 2018; Al-Ajmi, 2011; Albirini, 2006; Li \& Walsh, 2010; Macaro, Handley, \& Walter, 2012). In addition to relative advantages technology brings to the classroom, another factor that motivates teachers toward embracing technology is the support they receive from schools' principals and the match between technology and their needs and values (i.e., Compatibility). This finding is also in line with previous studies, which found that encouragement from principals has a positive impact on technology integration (e.g., Alkafyulilo et al., 2015; Li \& Walsh, 2010). Moreover, similar to other research findings (e.g., Albirini, 2006; Mumtaz, 2000), teachers use technology because technology is compatible with their needs (e.g., technology helps the teachers to achieve their lesson objectives quicker and easier, breaks the classroom routines and helps them to adopt new teaching methods) and their school's values (e.g., school's positive perceptions towards using technology). Despite the lack of formal training provided by the Ministry of Education, informal training among teachers motivated them towards using technology, which supports other research findings that highlight the importance of informal learning among colleagues (e.g., Afshari et al., 2009; Edgbert et al., 2002; Spiteri \& Rundgren, 2018).

Despite the positive attitudes, teachers hold towards using technology, this study found that EFL primary school teachers in Kuwait suffered from lack of parental support, lack of software and technical support, and the paucity of professional development training related to technology. These findings are in line with previous studies in other educational contexts (Albirini, 2006; Li \&Walsh, 2010; Pelgrum, 2002) and the Kuwaiti context (Al-Awidi $\&$ Aldhafeeri, 2017; Alfelaij, 2016). Although participants acknowledged the use of their personal technologies inside the classroom (e.g., IPad, PC, and data show projector), classroom infrastructure was not ready and 
supportive to integrate technology. This was evident from teachers' complaints about the classroom's lights, sockets and the unavailability of electronic devices. Furthermore, teachers suffered from the heavy workload, school's duties, and the rigid timetables, which prevented them from being creative and using technology. In addition, most of the teachers declared that the lack of technical support inside the classroom hindered their use of technology. Despite technology's relative advantages, findings revealed that teachers hesitate to use technology to avoid malfunction and technical problems. Agreeing with previous studies (Al-Awidi \& Aldhafeeri, 2017; Al-Harbi, 2012), Kuwaiti primary school teachers who participated in the study also lacked advanced ICT skills and confidence in using technology. According to Roger's diffusion of innovation theory, these issues are related to the complexity and trailability; this means that Kuwaiti primary school's teachers avoided using technology due to the difficulty they face when technology is used in the classroom. Not only complexity, but also trailability had a major impact on teachers' use of technology. Since Kuwaiti primary school's teachers were not provided by sufficient professional development training courses related to technology, teachers were uncertain about using technology pedagogically and technically. This uncertainty decreased the likelihood of technology adoption in the classroom.

The study's findings also highlighted an important point, which is related specifically to the Kuwaiti socio-cultural context: the lack of parental support, personal expenses, and health problems. Very limited studies discussed this issue when considering the implementation of technology (Afshari et al., 2009). It has been noticed that parents may hinder teachers' use of technology in the Kuwaiti context. Parents' negative attitudes towards technology and their rejection to let their children use technology outside the classroom's boundaries affected teachers' use of technology negatively. Furthermore, lack of appreciation and compensation hindered the technology integration. Teachers acknowledged that due to the lack of electronic resources, teachers use their personal devices, which cost them. Their devices were also vulnerable to malfunction and loss, and they would not be able to receive compensation for any repairs or replacements. Not only this, but they also mentioned health problems. Teachers complained that carrying heavy devices affected their health negatively.

\section{Conclusion}

This study was carried out to explore the factors that encourage and prevent teachers from using technology inside their EFL classrooms in Kuwait. Factors that encourage teachers to use technology were related to the benefits they gain from technology in their English language teaching, the support from schools especially from school's principals and colleagues and teachers' desire to change and innovate in their teaching practices. Several factors were reported as hindrance factors to technology integration, these are related to inadequate classroom infrastructure, lack of equipment, personal expenses and health problems, limited teachers' ICT skills and lack of professional development training related to technology, lack of time and lack of parental support.

The study has some limitations that need to be acknowledged. Firstly, all the participants were female teachers due to the nature of teaching staff in government primary schools in Kuwait; having mixed-gender samples could have illuminated more issues. Secondly, the study was exclusively limited to investigating the use of technology in particular classrooms in Kuwait; therefore, there was no attempt to generalize beyond the study's participants in these classrooms.

Despite these limitations, the study has several implications for policymakers. First, it was found that EFL teachers in Kuwait were eager to implement technology and integrate it effectively in the English curricula and their daily classroom practice, which will lead to mutual benefits for both teachers and students. Therefore, policymakers are advised to consider the challenges teachers confront when they use technology to facilitate the process of technology integration. It is recommended to provide professional development training on using technology that not only focuses on technical aspects but also pedagogical. Teachers need to be trained on how to use certain technologies to serve their pedagogical objectives. Although teachers believed that using technology promotes classroom interaction with digital native learners, they failed to select the suitable technologies that fit pedagogy in the Kuwait National curriculum. Therefore, the Ministry of Education is advised to organize training workshops where several Apps are recommended for teachers. Lack of technology equipment, poor classroom infrastructure and lack of technical support in schools are issues that need to be addressed by the Ministry of Education. To implement technology, classrooms need to be equipped with technologies such as data show projector and computer or interactive whiteboard. Also, Internet connection should be improved in government schools. Policymakers are also advised to consider parents' roles in technology integration. Schools' administrations should organize sessions for parents to help them develop positive attitudes towards using technology. Furthermore, the current study revealed that teachers in government schools have heavy workload and duties, therefore, it is recommended to reduce teachers' administration duties to allow them time for technology integration. 
The current study illuminated some factors that influence primary school teachers when using technology. Further research needs to be investigated to explore more factors that may affect teachers' use of technology by expanding the scope of research (e.g., focusing on middle and secondary school teachers). There is also a need to explore the effectiveness of teachers' education programs in preparing future teachers to use technology. Future research may focus on the relationship between teachers' cognition and their use of technology. Furthermore, researchers are advised to explore the role of parent support in technology integration and how this affects teachers' use of technology. Since the world is experiencing the Coronavirus pandemic and government schools are closed in Kuwait, future research should explore how to integrate technology in regular basis to make teachers, students and parent accepting it as first hand educational tool that can be used whenever we need to. School closure because of Coronavirus in all around the world showed the huge gap in educational system that lacks technology. Only schools and colleges, which were implementing technology in their teaching, were capable of continuing their academic year normally. Kuwaiti government schools were not capable of dealing with this crisis due to the limited use of technology.

\section{Acknowledgments}

The authors would like to thank the teachers who participated in this study and the Ministry of Education for providing access to government primary schools in Kuwait.

\section{References}

Afshari, M., Abu Bakar, K., \& Su Luan, W. (2009). Factors affecting teachers' use of information and communication technology. International Journal of instruction, 2(10), 77-98.

Agnes, C., \& Wallace, C. (2010). An investigation of factors affecting the use of ICT for teaching in the Western Cape schools (pp. 61-72). 18th European Conference on Information Systems, Pretoria, South Africa.

Ahmadi, M. (2018). The use of technology in English language learning: A literature review. International Journal of Research in English Education, 3(2). https://doi.org/10.29252/ijree.3.2.115

Al-Ajmi, S. (2011). Factors influencing information and communication technology implementation in government secondary schools in Kuwait. Retrieved from https://ore.exeter.ac.uk/repository/bitstream/handle/10036/3682/AlajmiS_fm.pdf?sequence=3

Al-Awidi, H., \& Aldhafeeri, F. (2017). Teachers' readiness to implement digital curriculum in Kuwaiti schools. Journal of Information Technology Education: Research, 16, 105-126. https://doi.org/10.28945/3685

Al-Harbi, G. (2012). Primary school teachers' perceptions regarding ICT usage and equipment in Kuwait. Journal of International Education Research, 8(1), 55-62. https://doi.org/10.19030/jier.v8i1.6696

Al-Kafyulilo, A., Fisser., P., \& Voogt, J., (2015). Factors affecting teachers' continuation of technology use in teaching. Educ Inf Technol, 21, 1535-1554. https://doi.org/10.1007/s10639-015-9398-0

Al-Sharija, M., Qablan, A., \& Watters, A. (2012). Principals', teachers', and students' perception of the information and communication technology in Kuwait secondary schools (rhetoric and reality). Journal of Education and Practice, 13(12), 91-99.

Albirini, A. (2006). Teachers' attitudes toward information and communication technologies: The case of Syrian EFL teachers. Computers and Education, 47, 373-398. https://doi.org/10.1016/j.compedu.2004.10.013

Alfelaij, B. (2016). Why integrating technology has been unsuccessful in Kuwait? An exploratory study. E-Learning and Digital Media, 13(3-4), 126-139. https://doi.org/10.1177/2042753016672901

Alkhezzi, F., \& Abdelmagid, R. (2011). Technology Integration: The Use of Computers by Elementary School Kuwaiti Teachers. JISTE, 15(2), 1-18.

Chambers, A., \& Bax, S. (2006). Making CALL work: Towards normalisation. System, 34, 465-479. https://doi.org/10.1016/j.system.2006.08.001

ChanLin, L.-J., Hong, J.-C., Horng, J.-S., Chang, S.-H., \& Chu, H.-C. (2006). Factors influencing technology integration in teaching: a Taiwanese perspective. Innovations in Education and Teaching International, 43(1), 57-68. https://doi.org/10.1080/14703290500467467

Cox, M., Webb, M., Abbott, C., Blakeley, B., Beauchamp, T., \& Rhodes, V. (2003). ICT and pedagogy: A review of the research literature. ICT in schools research and evaluation series, No. 18.

Creswell, J. (2007). Qualitative inquiry and research design: Choosing among five designs (2nd ed.). Thousand Oaks, CA: Sage. 
Egbert, J., Paulus, T. M., \& Nakamichi, Y. (2002). The impact of CALL instruction on classroom computer use: A foundation for rethinking technology in teacher education. Language Learning and Technology, 6, 108126.

Eickelmann, B. (2011). Supportive and hindering factors to a sustainable implementation of ICT in schools. Journal of Educational Research Online, 3(1), 75-103.

Erguvan, D. (2014). Instructors' perceptions towards the use of an online instructional tools in an academic English setting in Kuwait. The Turkish Online Journal of Educational Technology, 13(1).

Gutierrez, A. (2006). Sociocultural theory and its application to CALL: A study of the computer and its relevance as a mediational tool in the process of collaborative activity. ReCALL, 18(2), 230-251. https://doi.org/10.1017/S0958344006000620

Harvey, G., \& Hurworth, R. (2006). Exploring program sustainability: Identifying factors in two educational initiatives in Victoria. Evaluation Journal of Australasia, 6(1), 36-44. https://doi.org/10.1177/1035719X0600600106

Holloway, I., \& Wheeler, S. (2002). Qualitative research in nursing (2nd ed.). Oxford, UK: Blackwell publishing.

Jones, A. (2004). A review of the research literature on barriers to the uptake of ICT by teachers. Becta ICT Research. Retrieved from http://partners.becta.org.uk/page_documents/research/barriers.pdf

Kern, R. (2006). Perspectives on technology in learning and teaching languages. TESOL Quarterly, 40(1), 183210. https://doi.org/10.2307/40264516

Lam, Y. (2000). Technophilia vs. technophobia. A preliminary look at why second language teachers do or do not use technology in their classrooms. Canadian Modern Language Review, 56, 389-420. https://doi.org/10.3138/cmlr.56.3.389

Lamy, M., \& Hampel, R. (2007). Online Communication in Language Learning and Teaching. In C. Candlin \& D. Hall (Eds.), Research and Practice in Applied Linguistics Series. Houndsmills: Palgrave Macmillan. https://doi.org/10.1057/9780230592681

Li, L., \& Walsh, S. (2010). Technology uptake in Chinese EFL classes. Language Teaching Research, 15(1), 99125. https://doi.org/10.1177/1362168810383347

Macaro, E., Handley, Z., \& Walter, C. (2012). A systematic review of CALL in English as a second language: Focus on primary and secondary education. Language Teaching, 45(1), 1-43. https://doi.org/10.1017/S0261444811000395

Miles, M., \& Huberman, M. (1994). Qualitative data analysis: An expanded sourcebook (2nd ed.). Thousand Oaks, CA: Sage.

Mumtaz, S. (2000). Factors affecting teachers' use of information and communication technology: a review of the literature. Journal of Information Technology for Teacher Education, 9(3), 319-342. https://doi.org/10.1080/14759390000200096

Pelgrum, W. J. (2001). Obstacles to the integration of ICT in education: Results from a worldwide educational assessment. Computers \& Education, 37(2), 163-178. https://doi.org/10.1016/S0360-1315(01)00045-8

Rogers, E. M. (2003). Diffusion of innovations (5th ed.). New York, NY: Free Press.

Shadiev, R., \& Yang, M. (2020). Review of studies on technology enhanced language learning and teaching. Sustainability, 12. https://doi.org/10.3390/su12020524

Spiteri, M., \& Rundgren, S. N. C. (2018). Literature review on the factors afecting primary teachers' use of digital technology. Technology, Knowledge and Learning. https://doi.org/10.1007/s10758-018-9376-x

Sue, V., \& Ritter, L. (2007). Conducting Online Surveys. Thousand Oaks, CA: Sage. https://doi.org/10.4135/9781412983754

Warschauer, M. (2002). A developmental perspective on technology in language education. TESOL Quarterly, 36(3), 453-475. https://doi.org/10.2307/3588421

Warschauer, M., \& Kern, R. (Eds.). (2000). Network-based language teaching: Concepts and practice. Cambridge: Cambridge University Press Applied Linguistics Series. https://doi.org/10.1017/CBO9781139524735 
Warschauer, M., \& Meskill, C. (2000). Technology and Second Language Teaching and Learning. In J. Rosenthal (Ed.), Handbook of Undergraduate Second Language Education. Mahwah, NJ: Lawrence Erlbaum.

Yin, R. (2009). Case study research: Design \& methods. Thousand Oaks, CA: Sage.

Zhao, Y., \& Frank, K. A. (2003). Factors affecting technology uses in schools: An ecological perspective. American Educational Research Journal, 40(4), 807-840. https://doi.org/10.3102/00028312040004807

\section{Appendix A}

\section{Teachers' Questionnaire}

Dear teachers,

This questionnaire aims to gather some information about your computer usage, your current use of technology inside and outside the classroom and the technological training your received. The answers that you provide here will be used for my research purposes and your personal information and all other information will be anonymised.

\section{Part 1: You and your teaching experience}

Please tick the appropriate answer if applicable:

1) Gender Male $\square \quad$ female $\square$

2) Age $\quad 20-25 \square \quad 26-35 \square \quad 36-45 \square \quad 46-55 \square$

3) Which of the following educational qualifications or degrees do you have?

Bachelors degree $\square \quad$ Master degree $\square \quad \mathrm{PhD} \square$

4) Where did you get your bachelors degree?

Kuwait university $\square \quad$ College of basic education (PAAET) $\square$

Other (please specify)

5) Did you take any technology related course (e.g., Computer Assisted Language learning course) when you were undergraduate student?

$$
\text { Yes } \square \quad \text { (The course was...............................) } \quad \text { No } \square
$$

6) How long have you been teaching English?

$$
1-5 \text { years } \square \quad 6-10 \text { years } \square \quad 11-20 \text { years } \square \quad 20-30 \text { years } \square \quad \text { more than } 30 \text { years } \square
$$

\section{Part 2 Your skills and technology training:}

7) Have you received any training in using technology?

$$
\text { Yes } \square \text { (Go to Q3) No } \square \quad \text { Can not remember } \square
$$

8) Have you obtained ICDL certificate?

$$
\text { Yes } \square \quad \text { No } \square
$$




\section{Part 3: Technology use in the classroom:}

9) What motivates you to adopt technology into classroom practice?

\begin{tabular}{l}
\hline \\
\hline Technology helps me to change the way I teach \\
I am forced to adopt technology into teaching \\
All my colleagues are keen to use technology in teaching \\
It is becoming a trend to use technology in teaching \\
I like innovation \\
Language learning will become easy by using technology \\
Our school is very supportive in using technology in the classroom \\
Everyone is equipped with a computer for using in the classroom \\
Technology reduces my workload \\
We are trained to use technology in the classroom \\
It is easy to get promoted when you teach using technology \\
Technology makes teaching enjoyable \\
Children who do not like learning are motivated by technology \\
Using technology makes the lesson more interesting \\
Using technology allows me to present work to students which looks nicer than on the whiteboard \\
Technology provides numerous authentic materials for language learning \\
The interaction between teachers and students is becoming more when using technology \\
There are a lots of software packages available for me to use in teaching English to my students \\
I am good at using technology so I would like to try using it for teaching purposes \\
Technology helps students to practice grammar with immediate feedback
\end{tabular}

10) What prevents you from adopting technology into classroom practice?

\begin{tabular}{l}
\hline \\
\hline I have difficulty in using the computer myself \\
I don't know how to integrate technology in my teaching \\
I am not confident enough to use technology in front of my students \\
I don't have any types of technology to use in teaching \\
I can not find any relevant software packages to use them in teaching \\
I don't have time to prepare lesson using technology \\
There are not enough electronic resources \\
Lack of encouragement from school leaders \\
Lack of technician support in my school \\
Lack of students' computers which can be used in the classroom \\
Lack of access to a computer lab \\
Lack of skills to develop activities using technology for my students \\
Students are not well prepared to use technology in class \\
It will distract students' attention from learning \\
Lack of technological training \\
I don't think technology can make a difference to language learning \\
Students' negative attitudes towards using technology to learn \\
It reduces speaking time ; therefore, it is not good for language learning \\
I don't want to be different from other teachers
\end{tabular}


11) In what area would you like to get support to facilitate (better) technology integration into classroom practice?

\begin{tabular}{|c|c|c|}
\hline & Yes & No \\
\hline \multicolumn{3}{|l|}{ More computers that can be used in classroom } \\
\hline \multicolumn{3}{|l|}{ More access to internet or local network } \\
\hline \multicolumn{3}{|l|}{ More relevant software packages to choose from for my students } \\
\hline \multicolumn{3}{|l|}{ More training on how to use computer } \\
\hline \multicolumn{3}{|l|}{ More training on pedagogy in implementing technology into classroom } \\
\hline \multicolumn{3}{|c|}{ More technician support in class } \\
\hline \multicolumn{3}{|c|}{ More good examples to show how to successfully implement technology in teaching English } \\
\hline \multicolumn{3}{|c|}{ More support from school leaders } \\
\hline \multicolumn{3}{|l|}{ More encouragement from colleagues } \\
\hline \multicolumn{3}{|l|}{ More understanding from students and parents } \\
\hline \multicolumn{3}{|l|}{ Less stress from exams } \\
\hline \multicolumn{3}{|l|}{ Less homework to correct } \\
\hline \multicolumn{3}{|l|}{ Less time in monitoring and administrating students } \\
\hline Students are provided proper training to use technology to learn & & \\
\hline
\end{tabular}

Any other comments:

I will be following up this survey with in-depth interviews looking further at teachers' experience of ICT and what teachers perceive to be the important issues. If you are interested in this, please tick the box below, providing your name, current school and telephone number.

$\square$ I am interested in taking part in the interviews.

Name School

Telephone number

E-mail

Thank you for your participation 


\section{Appendix B}

Teachers' Semi-Structured Interview Schedule

\begin{tabular}{|c|c|c|}
\hline Topics & Sub-topic & Interview questions \\
\hline \multirow{7}{*}{$\begin{array}{l}\text { Teaching, education } \\
\text { and training } \\
\text { background }\end{array}$} & Education and Teaching & 1- What is your teaching background? \\
\hline & background & Prompts: \\
\hline & & - What qualifications do you have? \\
\hline & & - How long have you been teaching English? \\
\hline & & Which grades have you been teaching? \\
\hline & Training background & $\begin{array}{l}\text { 2-What teacher professional development training have you attended with } \\
\text { regards to }\end{array}$ \\
\hline & & a. Using technology? \\
\hline \multirow{13}{*}{ Use of technology } & IT skills & 3- How long have you been using a computer: in your personal life? \\
\hline & & 4- Can you assess yourself in terms of using a computer? \\
\hline & Perceptions of technology & 5- What do you think of using the following technology in one's personal life \\
\hline & & $\begin{array}{l}\text { e.g., Twitter, Facebook, Wikipedia, IPad, Blogs, PowerPoint, Chatting, Word } \\
\text { processor. }\end{array}$ \\
\hline & & Prompts: \\
\hline & & Which technologies do you think are beneficial? \\
\hline & & What benefits do you see in the use of these technologies? \\
\hline & & What limitations do you see in the use of these technologies? \\
\hline & The use of technology & 6- What technology do you regularly use yourself in your personal life? \\
\hline & & Prompt: \\
\hline & & Do you use technology such as email, chat forums etc. \\
\hline & & /Can you tell me how you normally use them? (i.e., for what purpose)? \\
\hline & & $\begin{array}{l}\text { Do you use technology such as Twitter, Facebook, blogs, wikis etc./For what } \\
\text { purpose? }\end{array}$ \\
\hline \multirow{13}{*}{$\begin{array}{l}\text { Using technology in } \\
\text { EFL classes }\end{array}$} & Perceptions & 7- What do you think of using technology in your EFL classes? \\
\hline & & $\begin{array}{l}\text { Prompts: What technology do you think is beneficial for you as a teacher/your } \\
\text { student? }\end{array}$ \\
\hline & & What benefits do you see in the use of technology? \\
\hline & & What limitations do you see in the use of technology? \\
\hline & Behaviors & 8- Which technologies do you use inside the classrooms? \\
\hline & & Prompts: How long have you been using them? \\
\hline & & -How do you use them? (i.e. your purposes) \\
\hline & & -What benefits do you see in the use of technology? \\
\hline & & -What limitations do you see in the use of technology \\
\hline & & -Have you encountered any difficulties in your teaching when using technology? \\
\hline & & -In your working environment, is there any support for teachers wishing to use \\
\hline & & technology in teaching? What kind of support, if any? \\
\hline & & -Why did not you use technology in your teaching? \\
\hline
\end{tabular}

\section{Copyrights}

Copyright for this article is retained by the author, with first publication rights granted to the journal.

This is an open-access article distributed under the terms and conditions of the Creative Commons Attribution license (http://creativecommons.org/licenses/by/4.0/). 